\title{
Spanish Geology Olympiad winners: What they think about their geology learning and the Olympics experience? A prospec- tive study
}

\author{
${ }^{1}$ Geology, Geography and Environment Department, Alcalá University, 28871 Alcalá de Henares, Spain \\ ${ }^{2}$ Geodynamics, Stratigraphy and Palaeontology Department, Complutense University of Madrid, 28040 Madrid, Spain; \\ *Corresponding author, E-mail: omidfesh@ucm.es
}

(Received: July 5, 2021; Revised accepted: September 10, 2021)

https://doi.org/10.18814/epiiugs/2021/021027

Among the initiatives that seek to promote earth sciences among young people are the Geology Olympics. This article analyses the perceptions of previous training among eleven of the winners of the first ten Geology Olympics held in Spain. This study also investigates the factors that have influenced young people to choose their university careers and their perceptions of the learning that participation in the Olympics has meant for them. The results indicate that the theoretical training they have received in the first cycle of secondary education has been limited and that practical content and geological field trips are practically nonexistent. Thus, only the good work of teachers has motivated them to take optional subjects such as geology and participate in activities such as the Olympics, which are a decisive factor in choosing university degree in Geology. Every participant changed their perspective of geology and its professionals after their participation in the Olympics. One of the aspects to consider is that more integrated and practical knowledge should be imparted in teacher training master's degree programs, as well as in providing more didactic instruments to future teachers so that they can implement better geological training for our young people.

\section{Introduction}

In 1959, the first International Mathematics Olympiad for pre-university students was held in Romania, and since then, other scientific Olympics have joined this initiative (Greco et al., 2013). The idea of an International Earth Sciences Olympiad arose within the International Geoscience Education Organization (IGEO), which is attached to the International Union of Geological Sciences (IUGS). The International Earth Science Olympiad (IESO) has been supervised by the IGEO and organized annually since 2007 . Spain joined this initiative in 2011, and since then, it has participated continuously, earning good results (Calonge and Greco, 2011).

The main objective of the Geology Olympics is to foster interest among secondary education students in geology and other sciences that study the dynamics of the Earth and planets. At the same time, these Olympics are a focal point of information for the general public, to draw attention to the importance of these disciplines in today's world and to offer teachers from different venues the opportunity to share good teaching practices. In this way, professionals from various fields of geology have spent years dedicating time, effort and enthusiasm to disseminate this science through means such as specific interventions in "Geology-days" or "Science Weeks". There have been proposals that the professionals of these sciences ought to make something similar to the Hippocratic Oath of health professionals such as the so-called Geoethical Promise, which was introduced by Matteucci et al. (2014). It, among others, expressly reflects the importance of each geologist committing to disseminate their scientific knowledge to society as a whole.

The feeling of the national organizers after conversations with the winners of the first ten editions of the Geology Olympics in Spain was that many of them, before participating in the Olympics, had not considered studying geology, and some did not even know about the existence of a university degree in geology. The assessment of the possibility that the Olympics have been a decisive factor in engaging the participants in geology and, as a consequence, their decision to pursue this university career has been one of the main drivers of this study. This type of study on the factors that lead students to choose one or another university degree has been carried out by the scientific and educational community from multiple points of view. For example, some have analysed the relationship between gender and the choice of university career (Navarro and Casero, 2012; Rodríguez et al., 2016), the socioeconomic conditions of the students, or their perceptions about job opportunities (Everis, 2013). However, after a bibliographic search, the authors have not found any work in the field of Earth Sciences that investigates the role that the Geology Olympics may have played in the final decision of the participating students to choose university studies related to these sciences.

\section{The Importance of Geology Studies}

Earth Sciences (ES) include a wide range of branches of knowledge that bring geology into contact with many other fields of research and 
development. Some contributions of the ESs are water security, energy security, natural risks, climate change, food security, space exploration or the search for mineral raw materials, essential for the development of many of today's new technologies, among many others. It is obvious that the future of human societies depends on solving problems like these.

In view of the aforementioned, basic geological education is essential to understand how our planet works and should be a priority of compulsory education (Pedrinaci et al., 2013). Planet Earth, and the changes it has undergone over time, is not a specific knowledge of a certain science but rather a cultural asset whose knowledge must be extended to all of society (Calonge et al., 2016).

\section{Geology in the Spanish Educational System}

Education in Spain is compulsory for all students between 6 and 16 years of age (Primary Education -6 to 12 years- and Compulsory Secondary Education -12 to 16 years-). Within the framework of the LOMCE, the content related to geology in the basic curriculum of Primary Education, Royal Decree 126/2014, are mainly included in the area of social sciences, in block 2: "The world in the one we live".

Within the framework of this law, Compulsory Secondary Education (E.S.O. in Spanish, Royal Decree 1105/2014) includes a subject called "Biology and Geology" in 1st, 3rd and 4th grades. The curricular summary of the geological contents for the 1st and 3rd year of ESO is included in two blocks. The first deals with the Earth in the Universe and the second with the terrestrial relief and its evolution. In the fourth year of ESO, topics related to geology are grouped in block "The history of the Earth", which includes content on the origin and history of the Earth, and introduces plate tectonics and its manifestations (from continental drift to plate tectonics).

The geological subjects in the first year of high school include classical content: structure and composition of the Earth, minerals and rocks, geological and petrogenetic processes, history of the Earth, etc. The subject of "Geology" (2nd year of high school) delves into the aspects dealt with in the first year and has geological time and plate tectonics as a common thread.

It is necessary to sequence the geology contents from the Primary to Baccalaureate stage. Part of the work is done since the geological content that all young people must know at the end of their compulsory education is included in the publication entitled "Literacy in Earth Sciences" (Pedrinaci et al., 2013). This work define the ten key ideas that should be reflected in the curricula of the educational systems and that should be the starting point from which the educational administrations consider an adequate sequencing of geological contents from Primary to Baccalaureate levels.

\section{Development of the Spanish Geology Olympiad}

At the national level, there are several competitions (Olympics) for secondary school students that focus on different science topics: mathematics, physics, chemistry, biology, geology, etc. The Spanish Geology Olympiad is one of the newest, and has become a fundamental initiative for pre-university students to learn and become interested in geology. Older Olympics have a greater number of participating students and schools, however it so happens that they are also subjects with a greater presence in educational curricula (for example, mathematics or physics compared to geology or biology, which are not always taught in the second year of high school). In all cases, the presence of Spanish students in international Olympiads has been increasing and the results obtained have improved (Carrión et al., 2001; Barba, 2011; Guirao and Romero, 2015).

The first edition of Geology Olympics took place in 2010, and the activity continued on an annual basis. To provide the highest possible quality, a team was established comprising approximately 30 people in charge of the different territorial Olympics and a support group made up of teachers from the Complutense University of Madrid, the Alcalá University and members of the Spanish Association for the Teaching of Earth Sciences (AEPECT).

Throughout these ten years, improvements have been made until reaching the current format (Fesharaki et al., 2020). The IESO is held every year and, since 2011, a Spanish team has participated and has progressively improved its results (Fig. 1). The acceptance that this scientific dissemination activity has had exceeded all the initial expectations of the AEPECT. Since 2018, this activity has had the support and funding of the Spanish Ministry of Education.

\section{Analysis of the Winners in the Ten Editions Celebrated Up To Now}

Although it is obvious that geology is a science, as we have commented previously, many students do not know what it is and what it is for, and even they overlook that it can be studied at the university. Thus, the experience developed in previous years has coincided with an increase in new students in the faculties in which the degree of geology is taught (Fig. 2), attributable in part to the participation of students in the Geology Olympics (Calonge, 2019).

To demonstrate the importance of the Olympics among Spanish students, Table 1 shows their results in the different international editions that have participated in. The excellent results obtained are evident, which translate into several gold, silver and bronze medals, as well as various diplomas for participation in the tests of the "International Team Field Investigation" and the "Earth System Project".

Of the 40 winning students of the National Phase (the first four classified in each of the ten editions held are considered winners), at least 11 have studied or are studying the Degree in Geology at a national university, which represents slightly more than $25 \%$. We also know that there are more participants who were in lower positions than the first four, and winners of the territorial phases, who have attended this university degree. We know that other participants and some of the winners have opted for careers related to geology such as geological engineering or environmental sciences, while most of the rest chose biology, physics, chemistry and degrees from the bio-sanitary branch.

\section{Methodology}

Given that one of the objectives of this work was to identify what factors led students who opted for this career to choose the Degree in Geology, an ad hoc questionnaire of ten questions was developed with an open response format and without limitations of space or time on this issue and others related to their interests prior to and after the 


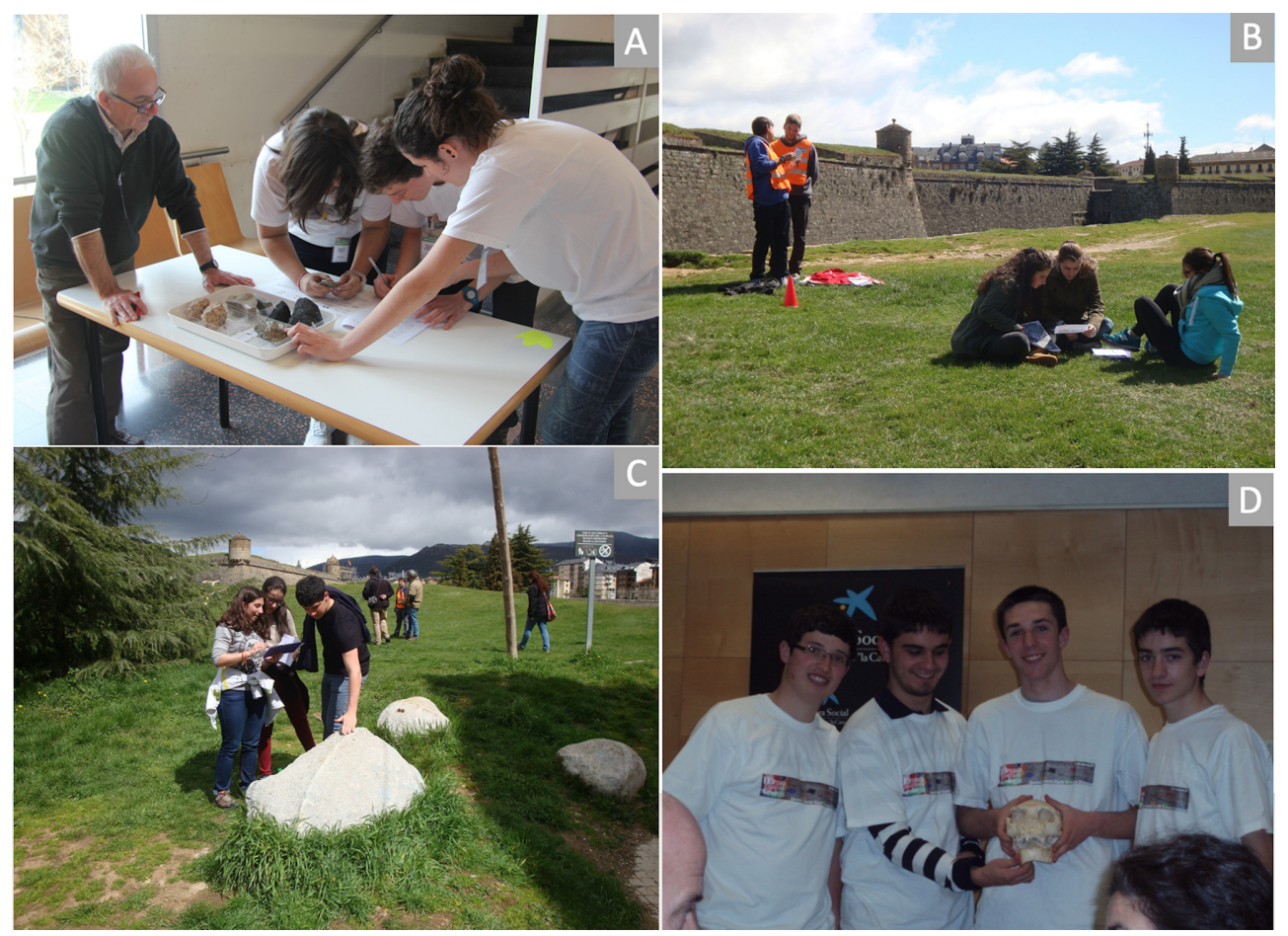

Figure 1. Photographs of different activities developed during the Geology Olympiads. (A) Tests conducted in classrooms and laboratories; (B) Tests conducted in the field; (C) Geo-gyncana; (D) Informative seminars and conferences.

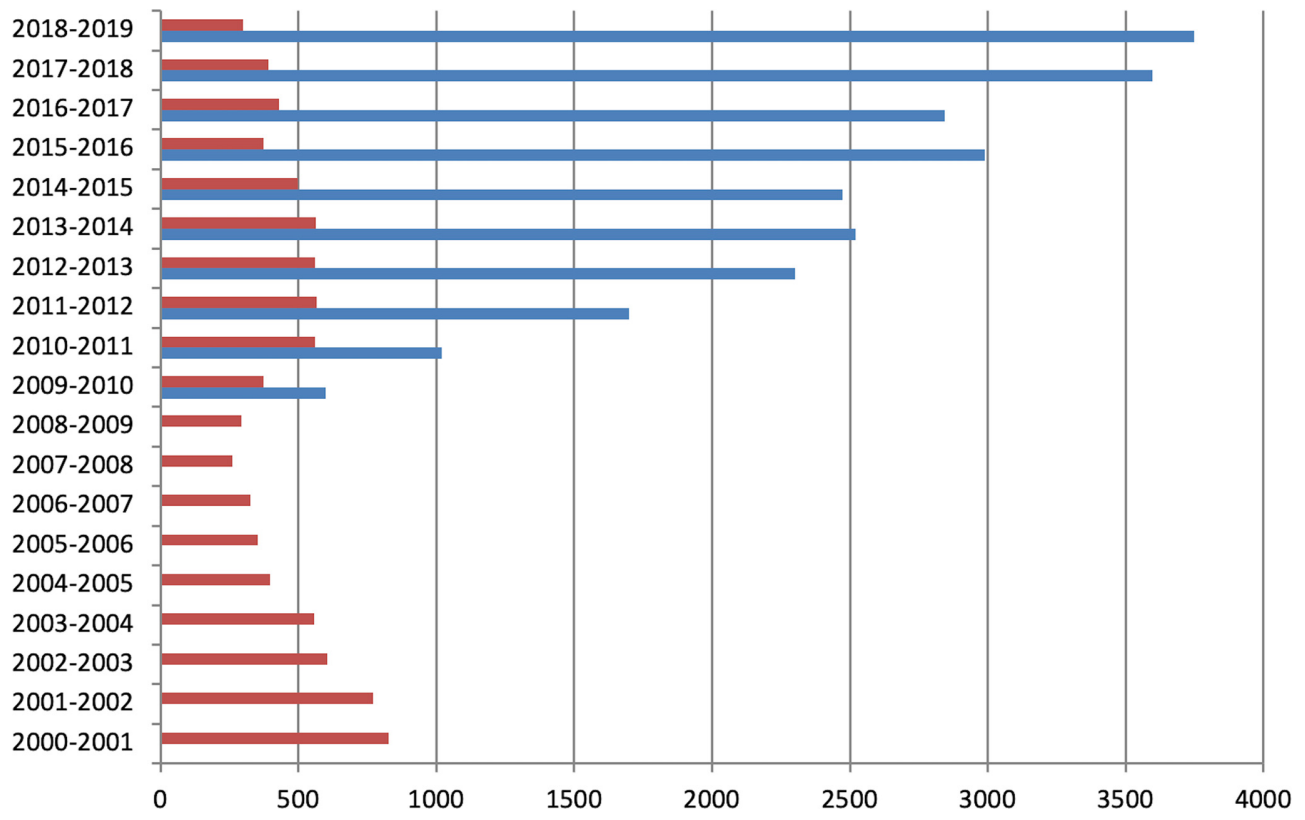

Figure 2. Comparison between the number of new students in Geology degrees (red bars) taught in Spanish universities and the number of students participating in the regional phases of the Geology Olympics (blue bars).

Olympics (see questionnaire in Annex 1). We propose a prospective study based on the case study of the winners of the Geology Olympics who have chosen to pursue university studies related to this science. For this reason, a qualitative methodology for analysing the data obtained from the questionnaires was chosen.

The questionnaire was divided into several blocks whose objectives were different. The questions in the first block (first 3 questions) sought to know the geological training that students had prior to their participation in the Olympics. The second block (questions 4 to 8 ) investigated the factors that influenced their decision to take geology, as well as different aspects of the influence that participation in the Olympics has had on their decisions. Finally, the last two questions (block 3) tried to infer their degree of motivation and satisfaction with the degree they are studying and their future professional possibilities. 


\section{Results and Discussion}

According to the results of the study, when analysing the origin of the winning students who have chosen to take a degree in geology, it should be noted that in most cases, they are students who resided in provinces that offer this degree in their universities (Barcelona, Madrid, etc.). This is not a minor fact since not all students want or can leave their residence, presumably in the family home, to move to other provinces where geology studies are offered. Therefore, this is a factor to take into account when evaluating the reasons that lead high school students to pursue a degree in geology. Of the eleven winners who are studying the degree in geology, seven are from provinces where this university degree is taught, while the other four have travelled to a nearby province to study these university degree (for example, from Malaga to Granada or from Teruel to Zaragoza). Figure 3 shows the provenance of the four winners of each year in relation to the provinces in which Geology degree studies are offered. It should be noted that it cannot be seen a regular trend to evaluate this provenance, so in future studies would be interesting to analyze whether the existence of the Geology degree studies affect the election of this university career in the different Spanish provinces.

\section{First Block: Questions 1 to 3}

\section{In relation to the pre-University training received}

The first three questions were jointly evaluated, and all related to the training in geology that was received before entering the university (Figs. 4A, B, C). Thus, the courses in which they received theoretical and practical training both in the laboratory and in the field were analysed.

Regarding the theoretical content on geology, the first thing that stands out is that all the surveyed students studied geology or earth and environmental sciences in the 2 nd year of the Baccalaureate. This is important, since the first is a subject that on many occasions is not offered in ESO centres (Fesharaki et al., 2019), and the second has

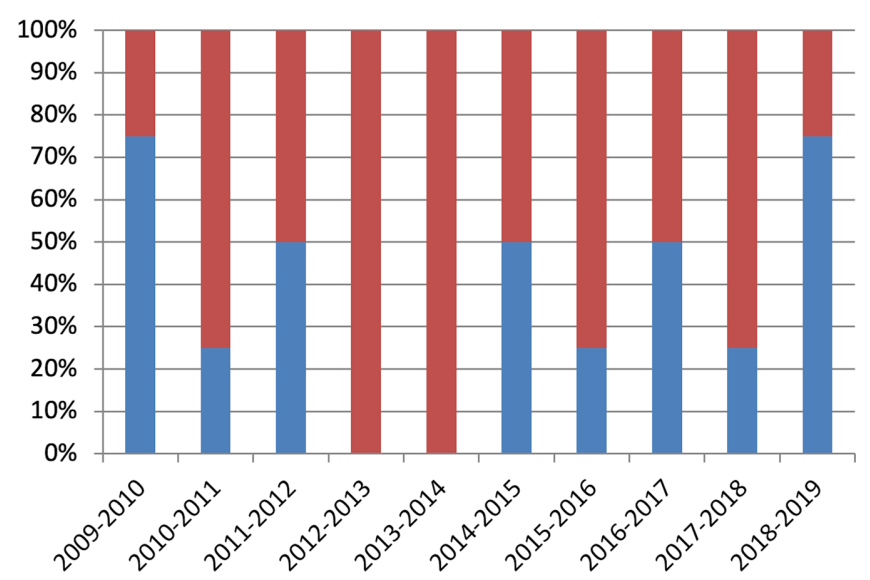

Figure 3. Graph in which the proportion of winning students who come from provinces offering the Degree in Geology (blue bars) is compared to those who come from provinces that do not have this university degree (red bars). more or less presence depending on the Autonomous Community. In addition, "Geology" is the subject that most fully develops the different branches of this science. Likewise, the fact of being taken in the 2nd year of Baccalaureate, with the possibility of taking it in an external test such as the EvAU (exam for the university career election), possibly increases the detailed and integrated knowledge acquired.

On the other hand, all the respondents indicated that they received theoretical training on geology in the subject of "Biology and Geology" of the 1st year of Baccalaureate, and from the answers of several of them, it is deduced that in a similar proportion to the theoretical part of biology. However, only half of those surveyed studied geology in the 4th year of the ESO. Even more alarming is the result regarding the geological formation they received in the first cycle of ESO. Only three studied geological content in the 3rd year of the ESO, and two in the 1 st year of the ESO (less than $20 \%$ of the surveyed students). In addition, several responses indicated that the time dedicated to geology versus biology was not more than $15-20 \%$, mostly at the end of the academic year. Finally, only one student indicated that he received some geological concepts in the 2nd cycle of Primary Education.

These results are unsatisfactory given that it is in these courses in which geology is part of compulsory subjects and, therefore, should reach all students. This fact is worry because some students do not receive a basic education on geology from the most applied point of view, in which all the explained concepts were related to their utility in future job opportunities. Recent studies have highlighted that to a large extent, the choice of a university career (or at least a training itinerary leading to certain careers) is formed between the Primary stage and the beginning of Secondary or that the factors that influence later are not succeeding in influencing that decision (Everis, 2013). In addition, as already indicated, essential aspects of geology, such as those related to the theory of plate tectonics, are taught from the 4th year of ESO, so young people who have not studied "biology and geology" of the 4th year of ESO (elective) will have finished their studies without having any notion about this integrating theory of a large part of the processes that occur in the geosphere.

Regarding pre-university training and practical classes on geology, it is evident that was only done in Baccalaureate studies. In addition, all indicate that the practices in the 1st Baccalaureate consisted of some sessions on rocks, minerals and fossils visu. Only two students mentioned other practices, such as crystal precipitation, sedimentation practices and water infiltration tests (porosity, permeability, etc.) and work with topographic profiles and simple geological sections. In addition, one of these students explained that as a project, group work was carried out using 3D printers to reproduce the regional geology of their place of residence and subsequently proceeded to its interpretation. Again, it is a fact that allows us to infer the reasons for the insufficient knowledge and, in part, the low assessment of geology as an experimental scientific discipline that students have. If ESO students do not have direct and repeated contact over time with the most experimental part (observation, description, making inferences or deductions, etc.) of this science, it is difficult for them to consider it a true science insofar as they receive information that seems immovable and without any relation to the reality of the students in its educational centres.

In the 2nd year of Baccalaureate, all students once again mentioned the $v i s u$ of rocks, minerals and fossils. However, they also mentioned practices of topographic profiles and geological sections (six students), 

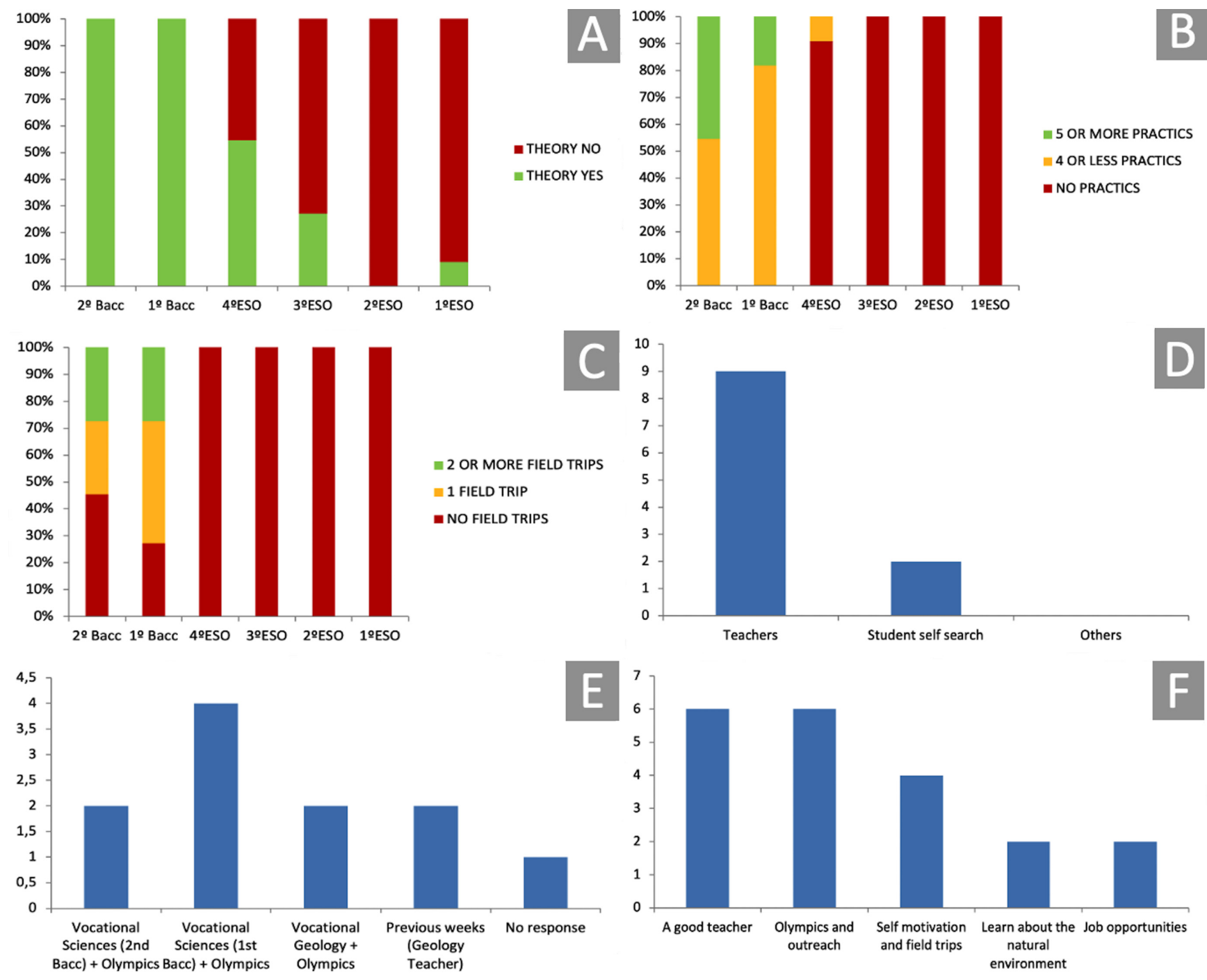

Figure 4. Graphic representation of the results obtained in some of the questions in the questionnaire. (A) Proportion of students who have studied geology theoretical content in various courses of secondary education; (B) Number of practices carried out by the surveyed students; (C) Number of field trips made by the surveyed students in each course; (D) Comparison between the different sources of information on the Geology Olympics; (E) Answers about the different moments in which the surveyed students decided to take the degree in Geology; (F) Different reasons for students to choose the degree in Geology (students could give more than one reason).

sedimentation practices and water infiltration tests, calculation of the epicentre of an earthquake, identification of geological structures and geomorphology practices with Google Earth (only one student in each case). A diversity of aspects dealt with during the practices is detected in the responses but it is still insufficient, as none of the students cites a work of "initiation to research" even a simply bibliographic one. Recent results of a study on the degree of scientific literacy of high school students of the scientific-technological option show that the students do not practice scientific procedures such as the design of an experiment or the formulation of hypotheses (Balastegui et al., 2020). In the same work, it was highlighted that the students of the humanities and social sciences develop better arguments and obtain better results in criticism and reflection of scientific activity. Both results support what has been commented in the previous lines and make visible the importance of delving into more applied aspects of geology.

In relation to the field practices carried out, all the students partici- pated in some field trips: five of those surveyed in the first year of Baccalaureate, three in the second year of High School and the rest in both the first and second years. Only one student mentioned more than one field experience in the same course. The places where they were held are obviously very different since they depend on the provinces of origin of these students (Barcelona, Madrid, etc.). However, certain similarities are observed in the objectives of these field practices. Thus, the most repeated objective is to know the lithologies of the place, identifying the most common rocks and sediments (six students). The observation and identification of geological structures (faults, folds, etc.) and geomorphological features are also cited as an objective (three students). Only two students indicated as objectives the learning of the location of elements or themselves on a topographic map or the reconstruction, from data collected and data provided by the teacher, of the geological history of the visited place. Another two mentioned field practices related to geological risks (karst and river areas). Finally, 
one student cites a practice related to environmental geology, also being the only mention of an activity in which joint biological and geological observations have been made (extraction of boulders in the artificial lagoon of El Campillo in Madrid) and the writing of a report. Among these last results, it is worth highlighting the small number of students (only three) who have had some contact with the collection of data, its treatment and the realization of a geological history or the integration of biological, geological and environmental data to write a report. The contact of the students in Baccalaureate, and even in ESO, with the collection of data, its statistical and graphic treatment, and the writing of a report on its results and interpretations, would not only bring them closer to many of the basic science and technology competences, but also allow them to incorporate aspects of competences such as linguistic communication, learning to learn, digital competence or even social and civic competences, once they work in teams or present their results and answer the questions raised by the teacher and their classmates.

\section{Second Block: Questions 4 to 8}

\section{Regarding the way they found out about the Olympics}

With the fourth question of the survey (Fig. 4D), the aim was to identify the sources through which the students received information about the possibility of participating in the Olympics (Internet, teachers, etc.), and to analyse whether participation in the Olympics was common in its institutes or if it was for the first time.

The results indicate several interesting facts: (1) nine students commented that they learned about the Olympics from their professor of Biology and Geology. Only two mentioned that it was their own inquiry on the Internet and their insistence that encouraged their teacher and/or centre to participate. (2) Except for the two cases mentioned above, all the others indicated that it was a common practice in their centres to participate in the geology Olympics in years prior to their promotion. (3) Of the nine students who indicated that it was their teacher's previous training that motivated them to participate in the geology Olympics, six indicated that the teacher was a geologist. Given that the number of respondents is small, decisive conclusions cannot be extrapolated, but it does seem that it is difficult to involve institutes that have not participated in this experience in the past. Possibly a factor to take into account is the lack of permanent positions of the teachers which makes them to move from one educational centre to a different one, in cases, every year. Also, it is important to note that the Biology Olympics was also difficult at the beginning for the participation of many educational centres, so perhaps it is only a matter of time (Barba, 2011). We must also consider the fact that the vast majority of Biology and Geology teachers of the High Schools have initial training as biologists, and probably prefer that their students participate in the biology Olympics with which they are more comfortable in the preparation phase than with geology items. Curiously, once institutions have participated, they usually repeat in successive years, and it could be said that their interest in this activity is loyal. It would be interesting as future lines of research to explore the reasons why the management of educational centres are reluctant to participate in these types of activities that have demonstrated their capacity to motivate students and their value as complements to formal secondary education training.

\section{In relation to their perception of learning that the Olympics has meant for them}

To understand this perception, the answers to the fifth and sixth questions were analysed to detect whether after their participation in the various phases of the Olympics, they changed their way of seeing this science and its professionals.

From the students' answers, it can be deduced that all have expanded their knowledge of geology after participating in the different phases of the Olympics, as well as in the preparation courses offered by some provinces prior to participating in the national phase and the course of training prior to the participation of the four winners in the international phase. This fact is common to other countries; thus, Greco and Costa (2014) explain that training for the Olympics allows improving the knowledge of the students who are involved. We reproduce below some of the answers to the $5^{\text {th }}$ question "Do you consider that today you know much more geology than you did before you started competing in the different phases of the Olympics?":

- "I firmly believe that after completing the different phases of the Geology Olympics, I have learned much more geology than I knew before starting to compete. Also, highlight the interest that participation in this event aroused in me when I discovered that Geology was what I really wanted to study [...]".

- "Yes, obviously, since I am studying the Degree in Geology. In the Olympics I learned a lot and in some way they contributed to my election of this career".

After analysing the answers to the sixth question, we realized that all the students, after their participation in the Olympics and the training courses, changed their perceptions of geology, their work methodology, its usefulness and their job opportunities. It is interesting to note that most of them emphasized that they discovered how transversal this science is and its interrelationships with the other sciences, as well as many fields of geology that they had not even heard of. Ibáñez et al. (2019) point out that a large portion of the ESO Biology and Geology textbooks do not show the same characteristics of experimental sciences nor do they depict the scientific methodology (for example, regarding the measurement of magnitudes) that is shown in the subjects of Physics and Chemistry. This would be one of the reasons why students sometimes have their first contact with geology as a true science only when they participate in the Olympics and in subsequent courses. This fact is very serious since it would relegate geology to be considered a purely rote subject, which the students could accept as already established and immovable knowledge, which is opposed to the very idea of a dynamic scientific discipline in which theories about various aspects of this science have emerged throughout history. We reproduce some of the most significant responses to the $6^{\text {th }}$ question "Has your way of seeing geology and the work of its professionals changed after participating in the Olympics and the preparation courses?":

- "Yes, I have been able to learn that geology is a transversal science, which is very useful in many aspects of life, from constructing a building, going through the exploitation of aquifers to obtain minerals used in many products of daily life".

- "Before participating, geology interested me, but not much more than other subjects I was studying; after the Olympics and, above all, the preparation courses, I ended up fascinated by its complexity and 
the ability to understand how the Earth works, as well as the tasks that a geologist must carry out in their work. So yes, I would say that the way I see it has changed drastically".

- "Yes, my way of seeing it has changed by getting to know it better [...]. I think it should be given more importance in the classroom [...]. I consider that the work of Geology professionals in comparison with the impact they have on society is not sufficiently valued nor is it shown the interest that, in my opinion, it should, and this is another factor that has changed my way of see Geology".

- "Hugely, [...] After the academic study and the Olympics process, I have not only acquired a lot of knowledge, but the concept I have of Geology is so broad and enriching that I consider that the professionals of the sector should be a key piece for the understanding of the environment, maintenance of the resources, development of materials and analysis of relevant natural phenomena".

\section{In relation to the factors that conditioned their decision to study Geology}

The seventh and eighth questions were used to analyse when they made the decision of the degree they would like to pursue, if this choice underwent many changes or was vocational, and if their decision was influenced by other factors such as outreach activities (Figs. 4E, F).

The seventh question ("From which year did you decide the university degree you wanted to do? Did you ever change your decision about the degree you wanted to study during ESO or Baccalaureate?") is the one that had the greatest diversity of responses on the questionnaire. It could be said that each student's interest came at a different time in his/her personal and academic life. Two students indicated that they had been vocational since childhood and that their choice was reinforced after participating in the Olympics. Other students indicate that they were vocational in science but that it was not until Baccalaureate that they decided on geology, in general after their participation in the Olympics and in other outreach activities. However, there were also two respondents who made the decision to pursue this degree a few weeks before having to officially choose a university career and who were mainly influenced by having had geology teachers in the 2nd year of baccalaureate that informed and encouraged them to make that choice. Similar responses have been observed in students participating in other Olympics, such as those in Brazil, in which, according to Castro et al. (2015), many young people were encouraged not only to participate in other scientific Olympiads but also to become scientists in the fields of geosciences. In other countries such as Italy, there is also a notable increase in the number of students in the first years of geology degrees at universities such as Modena or Reggio Emilia due, in large part, to the offer of activities in the style of the geology Olympics that allow dissemination among young people (Greco and Gualtieri, 2010; Greco et al., 2013).

Regarding the most decisive factors to expand university education in the Degree in Geology (question 8: "What would you say have been the two or three most influential factors for you to have decided to choose a Degree in Geology?"), the factors could be ordered based on the most cited: First, the most frequently mentioned was having a good teacher in Baccalaureate who instilled in them a passion for this science (six students). Second, participation in the Geology Olympics and to a lesser extent in other outreach activities motivated the decision (six students). Third, personal interest in Geology from a young age and their motivation for contact with it during field trips influenced four students. Fourth, the possibility of understanding the environment that surrounds us was attractive (two students). Fifth, possible job opportunities drew other two students toward the degree. In relation to these responses, we extracted some comments:

- "The teacher I had in 4th year of ESO and in Baccalaureate in Earth Sciences (this has been the most influential factor, without a doubt. She discovered Geology for me) and the beauty of being able to study the planet where we live".

- "Interest in Geology and Earth Sciences for many years before and as I have already mentioned the Olympics".

These results are of great importance since, on the one hand, they confirm that participating in dissemination activities of geology, among them the Olympics, influenced their subsequent choices. Thus, it would be important to change the inertia of many teachers and school managers to reduce non-regulated activities compared to more formal programming. On the other hand, it is interesting to note how the human factor has been decisive in the final choice of many of these students who indicated that their teachers were the ones who most influenced their decision. In this sense, we have important work to do in the training of future teachers. Master's degrees in teacher training should clearly emphasize the importance that all students, regardless of their training, have solid knowledge of all the subjects of biology and geology and the interrelationships between both sciences and, more importantly, students should receive training in how to approach certain topics of geology through more active and motivating methodologies, laboratory and office practices, field practices, group research work, etc. Only when teachers are prepared to deliver such a broad and diverse subject in a motivating way will they be able to show their students the richness of the earth and natural sciences, as well as the inevitable interactions that exist throughout the natural system (Fesharaki et al., 2019). But it is not only important to see the innumerable interactions between the fields of natural sciences, but also between the different branches of experimental sciences (physics, chemistry...). Thus, all branches of geology have important relationships with physical or chemical processes. Examples are earthquakes related to physical characteristics of the Earth or geochemical anomalies in relation to concentrations of metallic and industrial minerals.

\section{Third Block: Questions 9 and 10}

\section{In relation to the branches that they consider most attrac- tive and useful}

The ninth and tenth questions were aimed at identifying which branches of geology are most attractive to students and which they consider most useful (see Annex 1). In addition, the assessment was made by students who graduated from their training after completing the Degree in Geology.

In relation to the branches of geology that these students consider more attractive, there is a great disparity of opinions (mineralogy, palaeontology, geochemistry, geophysics, etc.), in part because only one of them is a graduate and, therefore, the rest have not yet taken all the subjects that make up the study plans of the Degree in Geology. In any case, the vast majority indicate that the most attractive thing for 
them is the training received in field practices and the large number of laboratory practices that are carried out. In addition, they highlight the spectrum of topics covered by the degree, so in the words of one respondent, "there is no time to get bored". Only a few respondents answered the question about the branches that they consider most useful for their future, a logical result if one considers that they have not yet received all the training and especially that related to the latest courses that are the most applied. Geotechnics and hydrogeology are mentioned as possible job opportunities.

The last question was only answered by one respondent who believed that his training has been good and supposed that he will have options, especially in the field of geotechnics.

Finally, some results have been inferred by a correlation between the different questions that could be argued for their interest. There is a very clear correlation between the students who indicate that they studied geology curricular contents in the first cycle of ESO with their subsequent decision to take elective subjects in "Biology and Geology" and "Geology". It is also clear that the students who most clearly know and value the true professional work of geologists (influencing their subsequent decision to pursue the Geology degree) are those who had a greater load of practical classes and greater number of field trips. That is, the more applied and closer to the real work of a geologist is the training offered to students (including more practices and field trips), the more likely they are to choose a career related to geosciences.

\section{Conclusions}

The results of this work show that the students who have completed degrees in geology are mostly from provinces where this degree is offered at their universities. In addition, most students received geological training in high school, while very few received any geological information in the first cycle of ESO, and when it existed, it was entirely theoretical. In general, the practical classes they received were scarce and not varied in their subject matter, and the field practices were mainly relegated to high school, although they were insufficient, and on a few occasions, they went from a merely expository visit to places of geological interest. Neither were they integrating the different branches of these sciences, and even less were the interactions between biology and geology shown to the students. These results clearly indicate that we are still a long way from reaching the guidelines set for literacy in earth sciences for secondary school students (Pedrinaci et al., 2013).

On the other hand, the surveyed students pointed out the good geology teachers they had in high school, their participation in the geology Olympics and, in some cases, their participation in other outreach activities as the main influencing factors in their decision to pursue university studies in geology. These results should encourage instructors of secondary education teachers to train master's degree earners to strive to teach a more practical and motivating methodology that prepares future teachers in their work to inspire students toward the natural sciences, specifically geology, because only in this way can we ensure interest in these branches of science.

The students surveyed in this work show a high level of satisfaction with the degree courses they are receiving and, the unique respondent that has finished the Geology degree believes that he will be able to practice as professional in these sciences. In addition, they all emphasize that once they had delved into the field of geology from their participation in the Olympics to their entry into universities, they were more aware of the importance of these sciences and believe that legislation and secondary education teachers should have them a lot more in mind.

Finally, we want to highlight that as the results of this work show, the Geology Olympics are playing an important educational role among secondary school students, fostering interest in this science. In addition, the experience of these years has coincided with a significant increase in new students in the faculties in which the degree of geology is taught, attributable in part to the participation of high school students in the Geology Olympics. Our short-term challenge is to apply these questionnaires to the winners of the territorial Olympics to obtain more complete information.

\section{Acknowledgements}

We thank the members of the National and territorial Organizing Committees of the Geology Olympics for the time and effort they dedicate each year for the Olympics to be a success. This work is a partial contribution to the Excellence Teaching Innovation Teaching Group of the University of Alcalá UAH-GI20-138, entitled: Development of skills through teaching innovation techniques. Additionally, the financial support of the project PID2020-113912GB-I00, from the Spanish Ministerio de Educación y Formación Profesional, is gratefully acknowledged. We would like to thank American Journal Experts (www.aje.com) for English grammar and style review. We are grateful for the suggestions made by two anonymous reviewers.

\section{References}

Balastegui, M., Palomar, R., and Solbes, J., 2020, En qu aspectos es más deficiente la alfabetización científica del alumnado de Bachillerato? Revista Eureka sobre Enseñanza y Divulgación de las Ciencias, v. 17, pp. 3302 .

Barba, J. L., 2011, La evolución de las Olimpiadas de Biología en España. Biólogos, v. 27, pp. 24-26.

Calonge, A., 2019, Olimpiadas de Geología: Cumplimos 10 años Enseñanza de las Ciencias de la Tierra, v. 27, pp. 125- 127.

Calonge, A., and Greco, R., 2011, Olimpiada Internacional de Ciencias de la Tierra (IESO): Una oportunidad a la Geología. Enseñanza de las Ciencias de la Tierra, v. 19, pp. 130-140.

Calonge, A., Brusi, D., and Juan, X., 2016, Current state of Geology Teaching in Spain. In: Greco, R., Almber, L. (Eds.), Earth Science Education: Global Perspectives. Pousoalegre, Brazil, pp 291-306.

Carrión, J.A., Tornos, J., Virto, A.A., and Rodríguez, S. 2001, V Olimpiada Iberoamericana de Física. Journal of Science Education, v. 2, pp. 111-113.

Castro, A.R.S.F., Aracri, E.M.R.P., Diogo, M.C., Greco, P.D., Mansur, K.L., and Carvalho, I.S.A., 2015, Olimpíada Brasileira de Geociências: contribuição para a popularização das Ciências da Terra. Terrae Didatica, v. 11, pp. 108-116.

Everis, 2013, Factores influyentes en la elección de estudios cientficos, tecnológicos y matemáticos. In: Visión de los estudiantes de 3 y 4 de ESO y Bachillerato. Generalitat de Catalunya.

Fesharaki, O., Calonge, A., and López-Carrillo, M.D., 2020, The educational role of Geology Olympiads in Spain: Promotion of the geological heritage and geoconservation in youngsters. Geoheritage, v. 12.

Fesharaki, O., Taboada-Trujols, I., and Sánchez-Pastor, N., 2019, Biomi- 
nerales del cuerpo humano: propuesta interdisciplinar para la Biología y Geología de Bachillerato. Revista de la Sociedad Geológica de España, v. 32, pp. 63-76.

Greco, R., and Costa, L.A., 2014, Análise de alguns casosnacionais de seleção e preparação para a International Earth Science Olympiad, IESO. Terrae Didatica, v. 10 , pp. 274-282.

Greco, R., and Gualtieri, A.F., 2010, Studio Geologia perch... Risultati preliminari sull' indagine quali-quantitativa relativa alla scelta del corso dilaurea in Scienze Geologiche. Geoitalia, v. 30, pp. 38-41.

Greco, R., Hlawatsch, S., and Bronte, N., 2013, The International Earth Science Olympiad (IESO): A way to raise public awareness of geoscience, particularly amongst younger people and enhance the quality of geoscience education international. Episodes, v. 36, pp. 235-239.

Guirao, A., and Romero, J.F. 2015, XVVI Olimpiada Internacional de Física. Revista de Física, v. 29, pp. 76-77.

Ibáñez, M.M., Romero, M.C., and Jiménez, M.P., 2019, Qu ciencia se presenta en los libros de texto de Educación Secundaria? Enseñanza de las

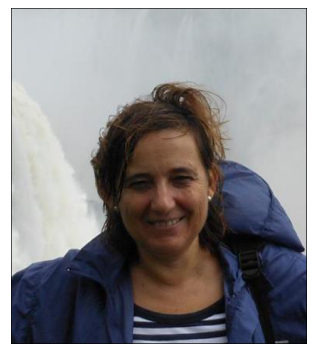

Amelia Calonge is professor of Geology in the University of Alcalá(Spain). As a researcher, she focused on the study of Middle Cretaceous' macro foraminifera and since 2002 , she has also been committed to the dissemination and teaching of Earth Sciences. She has been the director of many research projects and one of the research groups in Alcalá University: "Teaching Earth Science". She has also participated in European projects such as "Geoschools, teaching Geology" and "Shools tune into Mars". She has published many scientific articles and books and she has given several conferences. President of AEPECT (2006-2014). Vice-director and Director of several Departments in Alcalá University, and Dean of the Faculty of Education (2013-2019). She is the coordinator of Spanish Geology Olympiad in its different levels (local, national and international). As recognition of this dissemination activity, she was awarded the Honour Collegiate of the Official College of Geologists of Spain (ICOG).

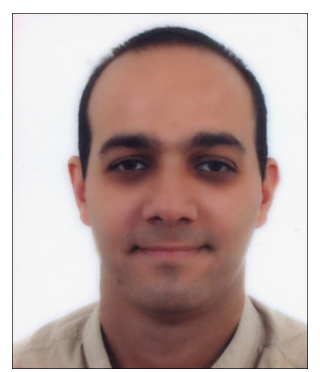

Omid Fesharaki has his $\mathrm{PhD}$ in Geology from the Complutense University of Madrid (Spain). His research interests are related to the analysis of paleoclimates and the study of the educational curriculum of secondary education for the proposal of motivating activities and teaching methodological improvements. He is a member of the organizing committee of the Madrid Geology Olympics. $\mathrm{He}$ is a member of the "Geodivulgar" innovation project (Complutense University of Madrid), in which he carries out a multitude of geology teaching and dissemination activities, especially aimed at people with functional diversity. He is the author of almost a hundred articles, book chapters and publications in conference proceedings and abstracts volumes. He has been awarded with individual and group awards for his activity in inclusive geology teaching.
Ciencias, v. 37, pp. 49-71.

Matteucci, R., Gosso, G., Peppoloni, S., Piacente, S., and Wasowski, J., 2014, The geoethical promise: a proposal. Episodes, v. 37, pp. 190-191.

Navarro, C., and Casero, A., 2012, Análisis de las diferencias de género en la elección de estudios universitarios. Estudios sobre Educación, v. 22, pp. 115-132.

Pedrinaci, E., Alcalde, S., Alfaro, P., Almodóvar, G.R., Barrera, J.L., Belmonte, A., Brusi, D., Calonge, A., Cardona, V., Crespo-Blanc, A., Feixas, J.C., Fernández-Martínez, E.M., González-Díez, A., Jímenez-Millán, J., Quintanilla, L., Rábano, I., Rebollo, L., Rodrigo, A., Roquero, E., 2013, Alfabetización en Ciencias de la Tierra. Enseñanza de las Ciencias de la Tierra, v. 21, pp. 117-129.

Rodríguez, M.C., Peña, J.V., and García, O., 2016, Estudio cualitativo de las diferencias de género en la elección de opciones académicas en los estudiantes del bachillerato científico-técnico. Teoría de la Educación, v. 28, pp. 189-207.

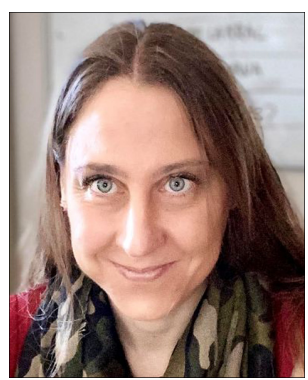

María Dolores López Carrillo has a $\mathrm{PhD}$ in Environmental Sciences from the University of Alcalá. Most of her research has focused on the Conservation and Disclosure of Paleontological Heritage. In recent years, her research has focused on scientific-didactic resources and strategies. She belongs to the UAH Research Group: "Investigate, Build and Create" where she develops educational research in the fields of innovative and active methodologies (ABP and interdisciplinary projects), STEAM, Robotics and Gamification. She is in charge of the subject "Learning based on STEM projects" in the recently created mention on "Knowledge of the Environment". At present she is coordinator of the 3rd year of the Primary Education Degree, and she has been the 3rd ViceDean of the Faculty of Education (in charge of the academic organization). In addition, she is the coordinator of the territorial Olympics of Geology. 


\section{Annex I}

In our desire to continue improving the experience of the Geology Olympics and to be able to achieve our goal of bringing the knowledge of this science to the entire Society, we want through some question accounts to assess how much participation in the different Olympics has served you (regional, national and international) of Geology. Please take a few minutes to fill out this questionnaire and be as honest as possible, that will help us improve...

1. Could you indicate in which courses you have received information related to geology? Mark with an X the boxes corresponding to those courses that you remember that you had a syllabus on this science.

\begin{tabular}{|c|c|c|c|c|c|c|c|}
\hline $\begin{array}{c}\text { First } \\
\text { cycle of } \\
\text { Primary } \\
\text { Education }\end{array}$ & $\begin{array}{c}\text { Second } \\
\text { cycle of } \\
\text { Primary } \\
\text { Education }\end{array}$ & $\begin{array}{c}1 \text { st } \\
\text { ESO }\end{array}$ & $\begin{array}{c}\text { 2nd } \\
\text { ESO }\end{array}$ & $\begin{array}{c}\text { 3rd } \\
\text { ESO }\end{array}$ & $\begin{array}{c}4 \text { th } \\
\text { ESO }\end{array}$ & $\begin{array}{c}\text { 1st } \\
\text { Baccalau- } \\
\text { reate }\end{array}$ & $\begin{array}{c}\text { 2nd } \\
\text { Baccalau- } \\
\text { reate }\end{array}$ \\
\hline
\end{tabular}

2. Do you remember having carried out any laboratory activity related to geology? If so, specify in which course and what type of internship you did.

3. Do you remember having made any field trip (excursion) related to geology? If so, specify in which course, where you went and what was the objective of that exit.

4. How did you find out about the possibility of participating in the regional Olympics? Was it common in your school or institute to appear at these Olympics in years prior to your promotion?

5. Do you consider that today you know much more geology than you did before you started competing in the different phases of the Olympics? In the event that your answer is that in some aspects yes and in others no, please specify in which subjects you have not noticed an increase in your knowledge.

6. Has your way of seeing geology and the work of its professionals changed after participating in the Olympics and the preparation courses? Explain how.

7. From which year did you decide the university degree you wanted to do? Did you ever change your decision about the degree you wanted to study during ESO or Baccalaureate?

8. What would you say have been the two or three most influential factors for you to have decided to choose a Degree in Geology?

9. Now that you are studying or have even finished it, which branch of this science do you like the most? Which one do you think will be most useful for your professional future?

10. For those who have already finished the Degree. Do you think that with your training you will be able to dedicate yourself to the profession of Geologist? Please, explain your answer. 